\title{
ZAKAT DAN PEMBAGIANNYA
}

\author{
Jumaria \\ Mahasiswa/I program studi ekonomi Syariah STAI AL-Azhar gowa \\ jumu101103@gmail.com
}

\begin{abstract}
Abstrak: Zakat merupakan ibadah dan merupakan kewajiban bidang harta dan benda dalam rangka mencapai kesejahteraan ekonomi dan mewujudkan keadilan sosial.zakat adalah sarana atau pengikat yang kuat dalam mengingkat hubungan vertical manusia dengan tuhan dan hubangan horizontal antara sesama manusia,khususnya antara yang berada dan tidak punya,dan saling memberi keuntungan batin(moril) dan fisik (material),baik dari pihak(mustahik) maupun dari pihak pemberi(muzaki).sedangakan pembagian zakat wajib dikeluarkan kepada delapan kelompok manusia, baik itu zakat fitrah maupun zakat mal, berdasarkan QS At-Taubah Ayat: 60 Apabila yang membagikan zakat itu adalah Imam, dia harus membaginya menjadi delapan bagian. Yang pertama kali mengambil bagian itu seharusnya adalah panitia zakat, karena dia mengambilnya sebagai ganti atas jerihpayah yang dikeluarkannya untuk memungut zakat. Adapun kelompok-kelompok yang lain mengambil zakat atas dasar kesamaan hak di antara mereka. Dan jika yang membagikan zakat itu adalah pemilik harta itu sendiri atau orang yang mewakilinya, gugurlah hak panitia zakat itu,kemudian dibagikan kepada tujuh kelompok yang tersisa jika semua kelompok itu masih ada. Jika tidak, zakat itu hanya dibagikan kepada kelompok yang ada saja.
\end{abstract}

Kata kunci: Zakat dan pembagianya

\section{A.Pendahuluan}

Zakat merupakan salah satu instrumen islami yang digunakan untuk distribusi pendapatan dan kekayaan.adanya zakat fitrah,zakat mal dan zakat profesi diharapkan dapat menekan tingkat ketimpangan kekayaan di Indonesia,selain itu juga zakat dapat diandalakn sebagai salah satu mekanisme dalam mengatasi masalah kemiskinan yang terjadi di Indonesia melalui program zakat produktif. ${ }^{1}$

- Zakat merupakan kegiatan yang wajib dilakukan bagi setiap umat Muslim yang dirasa mampu untuk melakukannya.Seperti halnya puasa dan salat.zakat adalah suatu ibadah maaliyyah ijtima,iyyah yang memiliki posisi sangat penting,strategis, dan mentukan yang baik dilihat dari sisi ajaran islam maupun dari sisi pembangunan kesejahteraan umat.sebagai suatu ibadah pokok,zakat termaksud salah satu rukun ke-3 dari rukun islam ke 5.di dalam al quran terdapat 27 ayat yang mengajarkan kewajiban sholat dan kewajiban zakat dalam berbagai bentuk kata .didalam al quran terdapat pula berbagai ayat yang memuji orangorang yang secara sungguh sungguh menunaikanya dan sebaliknya memberikan ancaman bagi

\footnotetext{
${ }^{1}$ Yoghi Citra Pratama, "Peran Zakat Dalam Penanggulangan Kemiskinan (Studi Kasus : Program Zakat Produktif Pada Badan Amil Zakat Nasional) [The Role of Zakat in Poverty Alleviation (Case Study: Productive Zakat Program at the National Amil Zakat Board)]," The Journal of Tauhidinomics 1, no. 1 (2015): 93-104.
} 
orang yang sengaja meninggalkanya.oleh karna itu khalifah abu bakar as shidiq bertekad memerangi orang orang yang sholat,tetapi tidak mau mengeluarkan zakat.ketegasan sikap ini menunjukan bahwa perbuatan meninggalkan zakat adalah suatu kedurhakaan dan jika hal ini dibiarakan,maka memunculkan berbagai kedurhakan dan kemaksiatan.adapun pembagian zakat yaitu sesuai dengan ketentuan-ketentuan yang telah di tetapkan. Orang-orang yang berhak menerima zakat hanya mereka yang telah ditentukan Allah SWT, dalam Al-Qur ${ }^{\text {ee } a n ~ m e r e k a ~ i t u ~ t e r d i r i ~ a t a s ~ d e l a p a n ~ g o l o n g a n . ~ B e r d a s a r k a n ~ f i r m a n ~ A l l a h ~ S W T: ~}$

Artinya: "Sesungguhnya zakat-zakat itu hanyalah untuk orang-orang fakir, orang-orang miskin, pengurus-pengurus zakat, para mualaf yang dibujuk hatinya, untuk (memerdekakan budak), orang-orang yang berutang, untuk jalan Allah dan orang-orang yang sedang dalam perjalanan, sebagai sesuatu ketetapan yang diwajibkan Allah, dan Allah maha mengetahui lagi maha bijaksana".(QS, At-Taubah : 60).

Ayat tersebut menunjukan bahwa yang berhak menerima zakat adalah delapan kategorimanusia

\section{B.Pengertian zakat dan kedudukannya dalam islam}

Ditinjau dari segi Bahasa,kata zakat merupakan kata dasar dari "zaka" yang berarti berkah,tumbuh,bersih,dan baik.sesuatu itu zaka berarti tumbuh dan berkembang,dan seorang itu zaka,berarti orang itu baik.zakat dari istilah fikih berarti:sejumlah harta tertentu yang di wajibkan allah untuk diserahkan kepada orang-orang yang berhak.(Qardhawi,2007).Adapun menururt sabiq(2006),zakat merupakan nama dari sesuatu hak milik allah yang dikeluarkan kepada fakir miskin.dinamakan zakat dikarenakan mengandung harapan untuk mendapatkan berkah,membersihkan,dan memumpuk jiwa dengan berbagai kebaikan.zakat merupakan salah satu dari lima rukun islam dan disebutkan secara beriringan dengan kata shalat pada 82 ayat didalam al-quran.allah telah menetapkan hukkum wajib atas zakat sebagaimana dijelaskan didalam al-quran ,sunah rasul,dan ijma ulama kaum muslimin .(sabiq,2006).hukum menunaikan zakat ialah wajib bagi setiap muslim yang telah memenuhi kriteria.

Menurut pendapat mayoritas ulama, zakat mulai disyariatkan pada tahun ke-2 Hijriah. Di tahun tersebut zakat fitrah diwajibkan pada bulan Ramadhan, sedangkan zakat mal diwajibkan pada bulan berikutnya, Syawal. Jadi, mula-mula diwajibkan zakat fitrah kemudian zakat mal atau kekayaan. Mengenai kewajiban zakat ini ilmuwan Muslim ternama, Ibnu Katsir, mengungkapkan, "Zakat ditetapkan di Madinah pada abad kedua Hijriah". Tampaknya, zakat yang ditetapkan di Madinah merupakan zakat dengan nilai dan jumlah kewajiban yang khusus, sedangkan zakat yang ada sebelum periode ini, yang dibicarakan di Makkah, merupakan kewajiban perseorangan semata. Sayid Sabiq menerangkan bahwa zakat pada permulaan Islam diwajibkan secara mutlak. Kewajiban zakat ini tidak dibatasi harta yang diwajibkan untuk dizakati dan ketentuan kadar zakatnya. Semua itu diserahkan pada kesadaran dan kemurahan kaum Muslimin. Menjelang tahun ke-2 Hijriah, Rasulullah SAW telah memberi batasan mengenai aturan-aturan dasar, bentuk-bentuk harta yang wajib dizakati, siapa

Sedangkan menurut basyir,zakat sudah pernah dilaksanakan sebelum kedatangan agama islam.kegiatan yang dilakukan yang berbentuk seperti zakat telah dikenal dikalangan bangsabangsa timur kuno di asia,khususnya dikalangan umat beragama.hal ini terjadi atas adanya pandangan hidup dikalangan bangsa-bangsa timur bahwa meninggalkan kesenangan duniawi 
merupakan perbuatan terpuji dan bersifat kesalehan.sebaliknya memiliki kekayaan dunia akan menghalangi orang untuk memperoleh kebahagian hidup disurga. ${ }^{2}$

Menurut lisanul arab arti dasar dari kata zakat ditinjau dari sudut Bahasa adalah suci,tumbuh,berkah,dan terpuji,semuanya digunakan dalam al-quran dan hadis.zakat dalam al-quran juga disebutkan dengan kata shadaqah itu adalah zakat dan zakat itu adalah shadaqah, berbeda nama tetapi sama artinya.

\section{C.Hukum dan syarat zakat.}

\section{Hukum zakat}

Zakat merupakan ibadah yang diwajibakan kepada setiap muslim yang berkaitan dengan harta dengan syarat-syarat tertentu.dasar hukum mengeluarkan zakat adalah:

\section{a.Al -baqarah : 42}

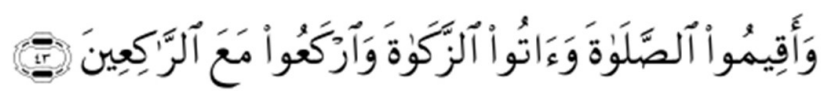

Artinya: "Dan dirikanlah shalat,tunaikanlah zakat dan rukuklah beserta orangorang yang rukuk”.

\section{b.At-taubah: 103}

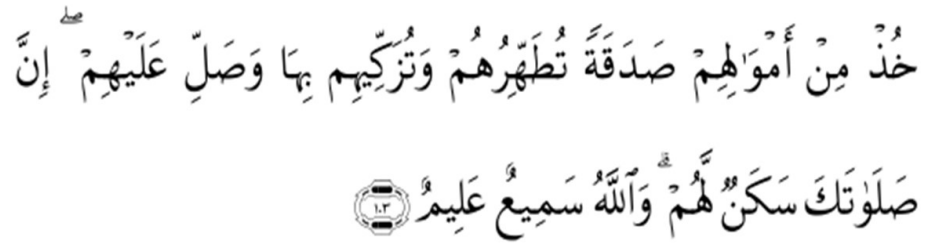

Artinya: "Ambillah zakat dari sebagian harta mereka,dengan zakat itu kamu membersihkan dan mensucikan mereka dan mendoalah untuk mereka.sesungguhnya doa kamu itu (menjadi) ketentraman jiwa bagi mereka dan allah maha mendengar lagi maha mengetahui.

\section{c.Al- Baqarah: 267}

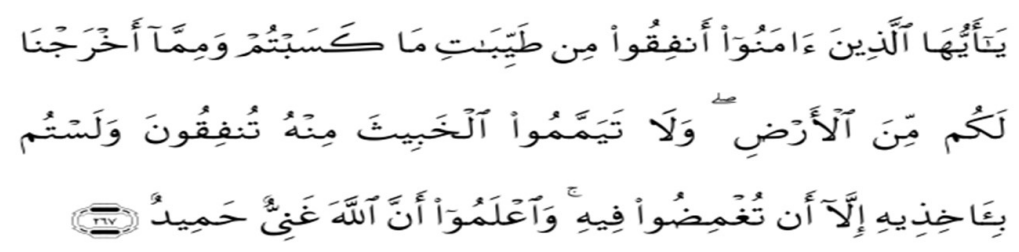

${ }^{2}$ Asnaf Zaka, T Menurut Pendapat, dan Imam Syafi, “ISSN Elektronik: 2442-2282 Volume: II, Nomor II. Juni 2015," 2015, 21-45. 
Artinya: "Hai orang-orang yang beriman,nafkahkanlah (di jalan allah) sebagian dari hasil usahamu yang baik-baik dan sebagian dari apa yang kami keluarkan dari bumi untuk kamu.dan janganlah kamu memilih yang buruk-buruk lalu kamu sendiri tidak mau mengambilnya melainkan dengan memicingkan mata terhadapnya.dan ketahuilah,bahwa allah maha kaya lagi maha terpuji."

Dasar Hukum tersebut zakat merupakan ibadah sosial yang wajib dilaksanakan oleh umat islam dengan syarat-syarat tertentu. Selain Al- Qur'an dan hadis terdapat juga dasar hukum formal yang dibuat oleh pemerintah tentang pengelolaan zakat seperti Undang-Undang no 23 tahun 2011 tentang pengelolaan zakat dan pengelolaan zakat ini juga diatur dalam PSAK 109 Akuntansi Zakat, infak, dan shadaqoh. ${ }^{3}$

\section{Syarat wajib zakat}

Persoalan yang sangat terkait dengan kewajiban zakat adalah atas siapa diwajibkan berzakat.telah disepakati oleh umat islam bahwa zakat hanya diwajibkan kepada sesorang muslim,merdeka,dewasa yang berakal yang memiliki kekayaan dalam jumlah tertentu.Adapun beberapa syarat wajib zakat yang harus diketahui yaitu:

a.Islam,pemilik harta diharuskan dari orang yang beragama islam karena berzakat merupakan ibadah yang diisyartakan kepada umat islam.

b.Berakal dan baligh,Seseorang yang sudah mengerti dan paham atas harta yang dimilikinya.

c.Berkecukupan mampu secara finansial,seseorang yang memiliki kelebihan dari kebuuhan pokoknya untuk sehari-hari maka wajib membayar zakat bagi muzzaki dan orang yang wajib dinafkahinya(termaksud untuk membayar hutang dan upah pembantu).

d.Merdeka,orang yang mengeluarkan zakat adalah orang yang merdeka,bukan dari kalangan budak atau hamba sahaya.

e.Hartanya memenuhi nisab,nisab ialah sebutan untuk kadar tertentu dari harta yang wajib dizakati.

f.Kepemilikan sempurna,pemilik harta yang hartanya dimiliki secara sempurna yang berada dalam kekuasanya.

\footnotetext{
${ }^{3}$ Landasan A Teori Zakat, "BAB II," n.d.
} 


\section{D.Harta wajib zakat}

1.Binatang ternak,syarat-syaratnya adalah sebagai berikut:

a.Perternakan telah berlangsung selama satu tahun.

b.Binatang ternak digembalakkan di tempat-tempat umum dan tidak dimanfaatkan untuk kepentingan alat produksi.

c.mencapai nisab.nisab untuk unta adalah 5 ekor,sapi 30 ekor,kambing atau domba 40 ekor.

d.ketentuan volume zakatnya sudah ditentukan sesuai karakteristik tertentu dan diambil dari binatang ternak itu sendiri.

2.Harta perniagaan, syarat-syaratnya adalah sebagai berikut.

a.Muzzaki harus menjadi pemilik komoditas yang diperjualbelikan,baik kepemilikanya itu diperoleh dari hasil usaha dagang mumpun tidak,seperti kepemilikan yang didapat dari warisan dan hadiah.

b. Muzakki berniat untuk memperdagangkan komodi- tas tersebut.

c. Harta zakat mencapai nisab setelah dikurangi biaya operasional, kebutuhan primer, dan membayar utang.

3.Harta Perusahaan Yang dimaksud perusahaan di sini adalah sebuah usaha yang diorganisir sebagai sebuah kesatuan resmi yang terpisah dengan kepemilikan dan dibuktikan dengan kepemilikan saham.

4.Hasil pertanian,adalah hasil tumbuh-tumbuhan atau tanaman yang bernilai ekonomis, seperti biji-bijian, umbi- umbian, sayur-sayuran, buah-buahan, tanaman keras, tanaman hias, rerumputan, dan dedaunan, ditanam dengan menggunakan bibit bebijian di mana hasilnya dapat dimakan oleh manusia dan hewan.

5.Barang Tambang dan Hasil Laut Yang dimaksud dengan barang tambang dan hasil laut adalah segala sesuatu yang merupakan hasil eksploitasi dari kedalaman tanah dan kedalaman laut.

6. Emas dan Perak Emas dan perak merupakan logam mulia yang memiliki dua fungsi, selain merupakan tambang elok sehingga sering dijadikan perhiasan, emas dan perak juga dijadikan mata uang yang berlaku dari waktu ke waktu. Syariat Islam memandang emas dan perak sebagai harta yang potensial atau berkembang. Oleh karena itu, leburan logam, bejana, souvenir, ukiran atau yang lainnya termasuk dalam kategori emas atau harta wajib zakat.

7. Properti Produktif ,yang dimaksud dengan adalah harta property yang produktifkan untuk meraih keuntungan atau peningkatan niai material dari property tersebut ${ }^{4}$.

\footnotetext{
${ }^{4}$ Latour Bruno, “Panduan Zakat Praktis,” Depag 53, no. 9 (2013): 1689-99.
} 
8.Tabungan dan invenstansi,apabila seseorang muslim memiliki harta yang telah disimpan terhitung mencapai satu tahun dan nilainya setara 85 gram emas maka wajib mengeluarkan zakat sebesar 2,5 persen.sementara,zakat invenstasi adalah zakat yang dikenangkan atas harta yang diperoleh dari hasil invenstasi yang dimiliki.seperti bangunan atau kendaraan yang disewakan.zakat invenstasi ditunaikan saat suudah menghasilkan,sedangkan modal tidak dikenai zakat.besar zakat yang dikeluarkan sebesar 5 persen untuk penghasilan kotor dan 10 persen untuk penghasil bersih.

9.Barang temuan ini adalah barang yang selama bertahun-tahun dan tidak diketahui pemiliknya.maka harta tersebut wajib ditunaikan zakat sebesar 20 persen.sebelum mengeluarkan zakat,harta tersebut harus memenuhi syarat yang telah ditetapkan yaitu:

a.kepemilikan penuh.

b.Harta halal dan diperoleh secara halal.

c.Harta yang dapat berkembang atau diproduktifkan (dimanfaatkan).

\section{E.Penerima zakat}

Delapan Golongan Penerima Zakat Penerima zakat berdasarkan surat At-Taubah ayat 60 terdiri dari delapan

golongan, yakni sebagai berikut:

\section{Fakir dan Miskin Fakir}

Fakir dan miskin yang disebutkan pertama secara berturut-turut dalam al-qur"an. Ini menunjukkan bahwa sasaran pertama zakat ialah hendak menghapuskan kemiskinan dan kemelaratan dalam masyarakat (Qardhawi, 1996: 510). Golongan fakir dan miskin adalah golongan yang harus diutamakan dalam penyaluran zakat, karena dalam AlQurean kedua golongan ini didahulukan. Dalam definisinya, ulama berbeda pendapat mengenai fakir dan miskin.Setengah ahli tahqiq mengatakan; bahwa fakir dan miskin itu satu golongan yang berbeda sifatnya, bukan berlainan suku. Fakir dan miskin itu satu, bukan dua golongan yang masing-masing berdiri sendiri (Shiddieqy, 1997: 166.sedangkan jumhur ulama,berpendapat bahwa keduanya adalah dua golongan tapi semacam.Maksudnya adalah mereka dalam kekurangan dan membutuhkan (Qardhawi,1996:510).

2. Amil Zakat

Golongan ketiga setelah fakir dan miskin yang berhak menerima zakat adalah amil zakat. Amil zakat adalah mereka yang melaksanakan segala macam urusan zakat, mulai dari pengumpul zakat samapi pada pembagian kepada mustahiq zakat. Amil zakat juga merupakan mereka yang melakukan perhitungan, pembendaharaan, pencatatan keluar masuknya zakat dan penjaga harta zakat. Bagi orang-orang ini Allah menjanjikan upah dari harta zakat yang diamanahi kepada mereka dan tidak diambil selain dari harta zakat (Qardhawi, 1996: 545). 
Amil menerima zakat sebagai ganti upah kerjanya (Az-Zuhaili, 2010: 283).Dalam pemberian zakat kepada amil tidak dipandang kekayaannya, karena pemberian kepada orang kaya adalah haram. Pemberian ini semata karena upah atas kerja yang ia lakukan. Pengurus zakat berhak mendapatkan zakat sesuai dengan kategori kepengurusan (AlUtsaimin, 2008: 211). Amil zakat diangkat dan ditugaskan oleh pemerintah (penguasa) atau suatu lembaga atau badan tertentu untuk mengurus segala urusan zakat. imam atau khalifah adalah orang-orang yang secara fikih berhak untuk bertindak sebagai amil zakat. namun demikian, golongan wajib zakat (muzzaki) menganggap suatu pemerintahan atau kekhalifahan kurang dapat memenuhi aspirasi golongan muzzaki, sehingga ditunjuklah dua golongan yang dianggap mampu melaksanakan segala urusan zakat, yang pertama dilingkungan yang cenderung tradisional (pedesaan) ditunjuklah tokoh-tokoh agama. Yang kedua, di daerah perkotaan dibuat panitia atau kelompok khusus yang dibentuk oleh organisasi atau lembaga keagamaan tertentu (Rahmad Hakim, 2018: 396).

3. Muallaf (Yang Dilunakan Hatinya).

Muallaf adalah golongan keempat yang berhak menerima zakat. Ulama

Fuqaha membagi muallaf dalam dua golongan, yakni:

a. yang masih kafir, kafir yang dimaksud adalah yang diharap akan beriman dengan diberikan pertolongan, dan ada pula kafir yang diberikan kepadanya hak muallaf untuk menolak kejahatannya;

b.yang telah masuk Islam terbagi kedalam empat kelompok, yang masih lemah imannya, pemuka-pemuka yang mempunyai kerabat, orang Islam yang berkediaman diperbatasan dan orang yang diperlukan untuk menarik zakat (Shiddieqy, 1997: 179180).

4.Riqab/hamba sahaya.

Mereka yang masih dalam perbudakan, dinamai riqab. Maksud riqab dalam alqur"an surat At-Taubah [9]: 60 adalah "segala mereka yang hendak melepaskan dirinya dari ikatan riqab atau perbudakan" (Shiddieqy, 1997: 183). Riqab adalah bentuk jamak dari raqabah, istilah ini dalam al-Qurean artinya budak belian laki-laki (abid) dan bukan belian perempuan (amah). Isitlah ini diterangkan dalam kaitannya dengan pembebasan atau pelepasan, maksudnya perbudakan bagi manusia tidak ada bedanya dengan belenggu yang mengikat. Membebaskan budak belian artinya sama dengan menghilangkan atau melepaskan belenggu yang mengikatnya (Qardhawi, 1996: 587). Riqab muktab adalah budak belian yang diberikan kebebasan untuk berusaha mengumpulkan kekayaan guna memerdekakan dirinya sendiri (Proyek Pembinaan Zakat Dan Wakaf, 1986).

Riqab dalam artian budak tidak relevan lagi di era sekarang, menginggat adanya penghapusan perbudakan dalam hukum postif nasional maupun internasional. Riqab di era sekarang lebih cenderung kepada mereka yang mengalami eksploitasi dan tertindas oleh golongan lainnya baik secara personal maupun kelompok. Riqab yang dimaksud disini adalah mereka yang menderita secara budaya maupun politik. 


\section{Gharim (orang yang berhutang ).}

Golongan keenam yang berhak menerima zakat adalah Gharimun (orang yang berutang). Gharimun adalah bentuk jamak dari gharim (dengan ghin panjang), artinya orang yang mempunyai utang. Sedangkan ghariim (dengan ra panjang) adalah yang berutang, kadangkala pula dipergunakan untuk orang yang mempunyai utang (Qardhawi, 1996: 594).

Gharimin ialah mereka yang mempunyai utang, tak dapat lagi membayar utanya, karena telah jatuh fakir (Shiddieqy, 1997: 185). Para ulama Rahimullah telah membagi utang menjadi dua bagian yaitu utang untuk mendamaikan dua hubungan dan utang untuk memenuhi kebutuhan (Al-Utsaimin, 2008: 213). Seorang gharimin yang terbelit hutang secara pribadi haruslah memenuhi syarat- syarat tertentu untuk dapat diberikan dana zakat. Qardhawi mengemukakan syarat-syarat bagi seorang gharimin pribadi, yang pertama dana zakat digunakan untuk membayar sisa hutangnya karena gharimin memiliki harta yang dapat digunakan untuk membayar hutangnya. Kedua, gharimin tidak melakukan pinjaman untuk tujuan maksiat atau keburukan. Ketiga, pembayaran utang dilakukan secara langsung dan yang keempat hutang bukanlah akibat kifarat atau zakat melainkan karena bisnis (Qardhawi,1996).

\section{Fisabillah (Di Jalan Allah).}

Golongan penerima zakat yang ketujuh adalah "sabilillah" (di jalan allah).Secara bahasa sudah jelas, sabil ialah jalan. Sabiullah ialah jalan baik berupa kepercayaan, maupun berupa amal, yang menyampaikan kita kepada keridhaan Allah (Shiddieqy, 1997).

Menurut Yusuf Al-Qardhawi dalam bukunya Fatwa- Fatwa Mutakhir, makna secara bahasa dari sabilillah terarah pada mardhatillah (keridhaan Allah). Dengan pengertian ini, maka segala bentuk kebaikan yang mendekatkan manusia dengan Tuhannya termasuk dalam makna sabilillah.Makna sabilillah dalam Al-Qur"an surat AtTaubah terlalu umum, sehingga banyak menimbulkan perbedaan perspektif. Sebab makna sabilillah di luar ayat ini sangat umum dan mencakup banyak hal, tidak terbatas pada penerapan golongan-golongan yang berhak menerima zakat saja. Sabilillah secara umum juga mencakup pemberian bantuan atau pertolongan kepada tujuh golongan lain dalam asnaf (golongan) penerima zakat (Al-Qardhawi, 2006: 372).

\section{Ibnu Sabil}

Jumhur ulama mengkiaskan ibnu sabil dengan musafir, yaitu orang yang berpergian dari satu daerah ke daerah lainnya. As-sabil secara bahasa berarti ath- thariq atau jalan (Al-Utsaimin, 2008). Menurut imam syafiec i ibnu sabil adalah orang yang dalam perjalanannya kehabisan bekal ataupun orang yang bermaksud melakukan perjalanan namun tidak mempunyai bekal, keduanya berhak menerima zakat untuk memenuhi kebutuhannya, karena melakukan perjalanan bukan untuk maksud maksiat. Sedangkan menurut Yusuf Qardhawi, tidak setiap orang yang melakukan perjalanan demi 
kemaslahatan diberi bagian zakat, walaupun perjalanannya untuk suatu kemanfaatan tertentu (Qardhawi, 1996: 654-655). Selain orang-orang yang melakukan perjalanan, anak-anak yang terlantar dijalanan juga termasuk dalam ibnu sabil. Mereka yang tidak memiliki rumah dan menjadi gelandangan dijalanan juga termasuk dalam golongan ibnu sabil. Oleh karenya, biaya untuk menyekolahkan dan membiayai para gelandangan ini adalah dapat diambil dari dana zakat untuk golongan ibnu sabil (Rahmad Hakim, 2018: 400-401). ${ }^{5}$

\section{Kesimpulan}

\section{Pengertian zakat}

- Zakat merupakan kegiatan yang wajib dilakukan bagi setiap umat Muslim yang dirasa mampu untuk melakukannya.Seperti halnya puasa dan salat.zakat adalah suatu ibadah maaliyyah ijtima,iyyah yang memiliki posisi sangat penting,strategis, dan mentukan yang baik dilihat dari sisi ajaran islam maupun dari sisi pembangunan kesejahteraan umat.sebagai suatu ibadah pokok,zakat termaksud salah satu rukun ke-3 dari rukun islam ke 5. di dalam al quran terdapat 27 ayat yang mengajarkan kewajiban sholat dan kewajiban zakat dalam berbagai bentuk kata .didalam al quran terdapat pula berbagai ayat yang memuji oran gorang yang secara sungguh sungguh menunaikanya .dan sebaliknya memberikan ancaman bagi orang yang sengaja meninggalkanya.

\section{Hukum dan syarat wajib zakat}

a.Hukum zakat.

Dasar hukum dikeluarkanya zakat merupakan hal yang wajib harus dilaksanakan umat muslim sesuai dengan harta dan syart-syarat tertentu yang telah ditetapkan.

b.Syarat wajib zakat yaitu:

- Islam.

- Berakal dan baligh.

- Berkecukupan/ mampu secara finansial.

- Merdeka.

- Hartanya memenuhi nisab.

\footnotetext{
${ }^{5}$ Riski Sulistiarini Tiara Dewi, Muhammad Amir Masruhim, “済無No Title No Title No Title,” Laboratorium Penelitian dan Pengembangan FARMAKA TROPIS Fakultas Farmasi Universitas Mualawarman, Samarinda, Kalimantan Timur, no. April (2016): 5-24.
} 
- Kepemilikan sempurna.

3. Harta wajib zakat

Adapun harta wajib zakat ialah:

- Binatang ternak.

- Harta perniagaan.

- Harta perusahaan.

- Hasil pertanian.

- Barang tambang dan hasil laut.

- Emas dan perak.

- Propeti.

- Tabungan dan invenstasi.

- Barang temuan.

\section{Penerima zakat}

Adapaun g penerima zakat ada 8 golongan yaitu:

- Fakir dan miskin.

- Amil zakat.

- Muallaf (yang dilunakan hatinya).

- Riqab (hamba sahaya).

- Gharim (orang yang berhutang ).

- Fisabilillah (dijalan allah).

- Ibnu sabil. 


\section{Daftar Pustaka}

Bruno, Latour. "Panduan Zakat Praktis.” Depag 53, no. 9 (2013): 1689-99.

Pratama, Yoghi Citra. "Peran Zakat Dalam Penanggulangan Kemiskinan (Studi Kasus : Program Zakat Produktif Pada Badan Amil Zakat Nasional) [The Role of Zakat in Poverty Alleviation (Case Study: Productive Zakat Program at the National Amil Zakat Board)]." The Journal of Tauhidinomics 1, no. 1 (2015): 93-104.

Teori Zakat, Landasan A. "BAB II," n.d.

Tiara Dewi, Muhammad Amir Masruhim, Riski Sulistiarini. “済無No Title No Title No Title." Laboratorium Penelitian dan Pengembangan FARMAKA TROPIS Fakultas Farmasi Universitas Mualawarman, Samarinda, Kalimantan Timur, no. April (2016): 5-24.

Zaka, Asnaf, T Menurut Pendapat, dan Imam Syafi. "ISSN Elektronik: 2442-2282 Volume: II, Nomor II. Juni 2015," 2015, 21-45. 